\title{
Study on Compressive Strength and Moisture Content of Different Grades Density of Foam Concrete
}

\author{
Wen-Wu LONG ${ }^{1, a}$, Jing-Song WANG ${ }^{2, b,{ }^{*}}$
}

${ }^{1}$ School of Urban Construction, University of South China, Hengyang, Hunan 421001, PR

a1183608316@qq.com, bxhwjs@163.com

${ }^{*}$ Corresponding author

Keywords: Foam Concrete, Dry Density, Moisture Content, Compressive Strength, The Drying Temperature.

\begin{abstract}
Influences of curing period and dry density on Moisture content and compressive strength were investigated through eight different densities of foamed concrete be in $650 \mathrm{~kg} / \mathrm{m}^{3}$ to $850 \mathrm{~kg} / \mathrm{m}^{3}$. The research results show that foam concrete in same age stages with increasing dry density, compressive strength increased, while reducing the moisture content; With an increase in the dry density grade, the compressive strength was significantly enhanced; the relation between the foam concrete compressive strength and moisture content reached 0.9939 .
\end{abstract}

\section{Introduction}

Load-bearing concrete structures commonly use high performance concrete that require a higher mechanical properties and durability. Density of high performance concrete is usually about $2400 \mathrm{~kg}$ $/ \mathrm{m}^{3}$. Non-load-bearing infill walls is filled in framework walls that have less demands on the mechanical properties.so the research of new energy saving materials with light weight can be used in walls have important significance. Dry density of foam concrete is used to infill walls is generally $800 \mathrm{~kg} / \mathrm{m}^{3}$ (is only a quarter of normal concrete density). Foam concrete with light weight, thermal insulation, energy-saving, soundproofs, anti-seismic, non-flammable and other outstanding features, is a line with national energy saving green new wall materials.

There were many studies on the production of foam concrete formulations, foaming agents, admixtures, additives, etc. Practical production technology of foam concrete was researched by Yan Zhenjia and He Yanjun[1]. Wang Wuxiang, Zhang Leilei Had done many researches on the concrete production formula[2]. Wang Cuihua, Yin Bing, Yu Shuijun, Ding Qi had done deeper study on foaming agents [3-6]. Excellent properties of foam concrete are due to its lot, small, independent, closed pores. Tiny pores have a greater impact on the moisture content of foam concrete. At present, there are less experimental researches about moisture content of concrete foam, so it is necessary to do research in moisture content of foam concrete.

\section{Experiment}

\section{Materials and Major Laboratory Equipment}

Experimental Materials. Cement: $\mathrm{P} \bullet \mathrm{O}$ 42.5;Xiangjiang river sand (Intermediate sand); Foaming agents: animal protein foaming agents; curing agent; Early- strength agent; Water reducing agent; Alkali-resistant glass fiber.

Major Laboratory Equipment. Pressure Testing Machine; Oven; Weighing-machine.

\section{Experimental Program}

Compressive strength and water content of eight groups foam concrete was test when its curing period is $1 \mathrm{~d}, 3 \mathrm{~d}, 7 \mathrm{~d}, 14 \mathrm{~d}, 21 \mathrm{~d}, 28 \mathrm{~d}$. Law of compressive strength and moisture content was studied by each group of foam concrete. Influence of Standard curing period and dry density on compressive strength of foamed concrete. The relationship between compression strength and water content was studied at $60{ }^{\circ} \mathrm{C}$ drying temperature when its curing period is $28 \mathrm{~d}$. 


\section{Making Process and Performance Testing}

Preparation of Foam Concrete. (1)The air and animal protein foaming agent were mixture into a bubble by high pressure air foaming machine. The Bubble has a fast speed, high efficiency, small bubble diameter, delicate, etc.(2)Firstly, cement, river sand, according to a predetermined measurement, were mixed evenly in a blender, Secondly, added water and water reducing agent, Thirdly, added Alkali-resistant glass fiber and early-strength agent, foam, stirred well (tested wet slurry density, so as to control the dry density of foam concrete), the last, foam concrete slurry was made. The making process should control at about $15 \mathrm{~min}$.(3)Foam concrete slurry was poured into the prepared concrete shaping mould $(100 \mathrm{~mm} * 100 \mathrm{~mm} * 100 \mathrm{~mm}$ ), after a day, a good forming block was moved to the standard curing room for maintenance.

Test Procedure of Compressive Strength. Remove block from the standard curing room, with a dry towel dry the water on the surface of the block, do the compressive strength test, and then test the moisture content.

Moisture Test. (1)According to Foam concrete ( JGT266-2011), three pieces of specimen are put in the oven whose temperature is $(60 \pm 5){ }^{\circ} \mathrm{C}$ to dry for 4 hours, making the weight difference is not greater than $1 \mathrm{~g}$. The specimen should be placed within the dryer and cooled to room temperature. Dry weight of the specimen is precisely at the $1 \mathrm{~g}$. Dry density and moisture content is calculated separately by (1), (2):

$$
\begin{aligned}
& \rho_{1}=\frac{m_{0}-m_{1}}{V} \times 10^{6} \\
& w_{1}=\frac{m_{0}-m_{1}}{m_{1}} \times 100 \%
\end{aligned}
$$

Remark:

$\rho_{1}$ - Dry density, kilograms per cubic meter $\left(\mathrm{kg} / \mathrm{m}^{3}\right)$, accurate to $0.1 ; m_{0}$ — the weight of the block that dry with a towel after the block is take out standard curing room, unit: Grams $(\mathrm{g})$;

$m_{1}$ — the block drying (drying temperature is $60{ }^{\circ} \mathrm{C}$ ) weight, unit: Grams $(\mathrm{g})$;

$w_{1}$ - the moisture content of the block (drying temperature of $60{ }^{\circ} \mathrm{C}$ );

$V$ - the volume of the block, unit: three square millimeter $\left(\mathrm{mm}^{3}\right)$;

\section{Experimental Results and Analysis}

The Relationship between Dry Density and Compressive Strength with Dry Density and Moisture Content about Foam Concrete in Different Curing Period. (See Figure 1 to 6)

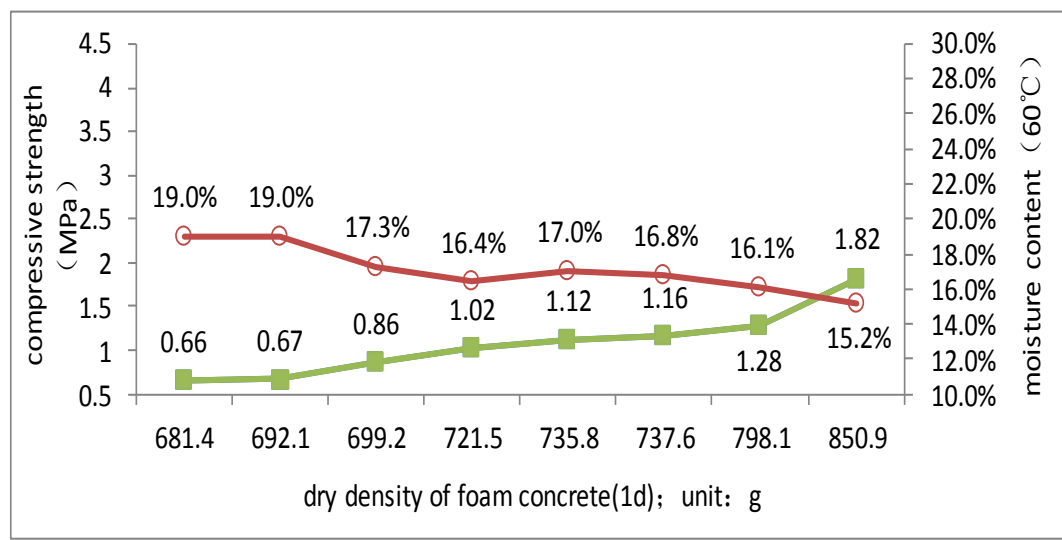

Fig.1 Effects of dry density of foam concrete on compressive strength and water content

(Maintenance period for 1d) 


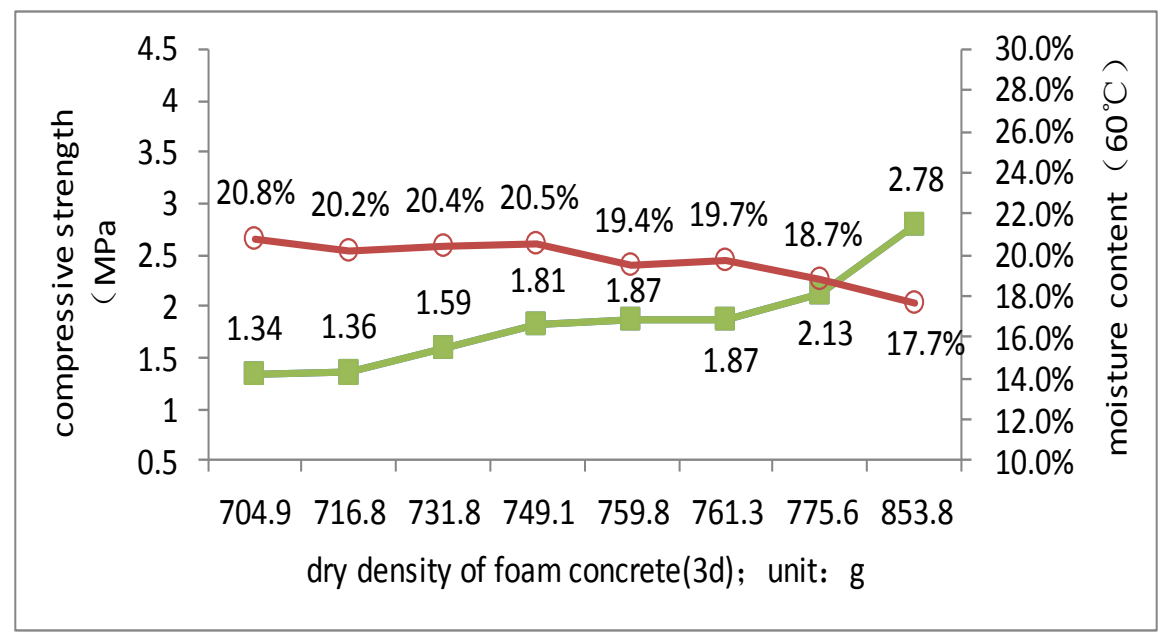

Fig.2 Effects of dry density of foam concrete on compressive strength and water content (Maintenance period for 3d)

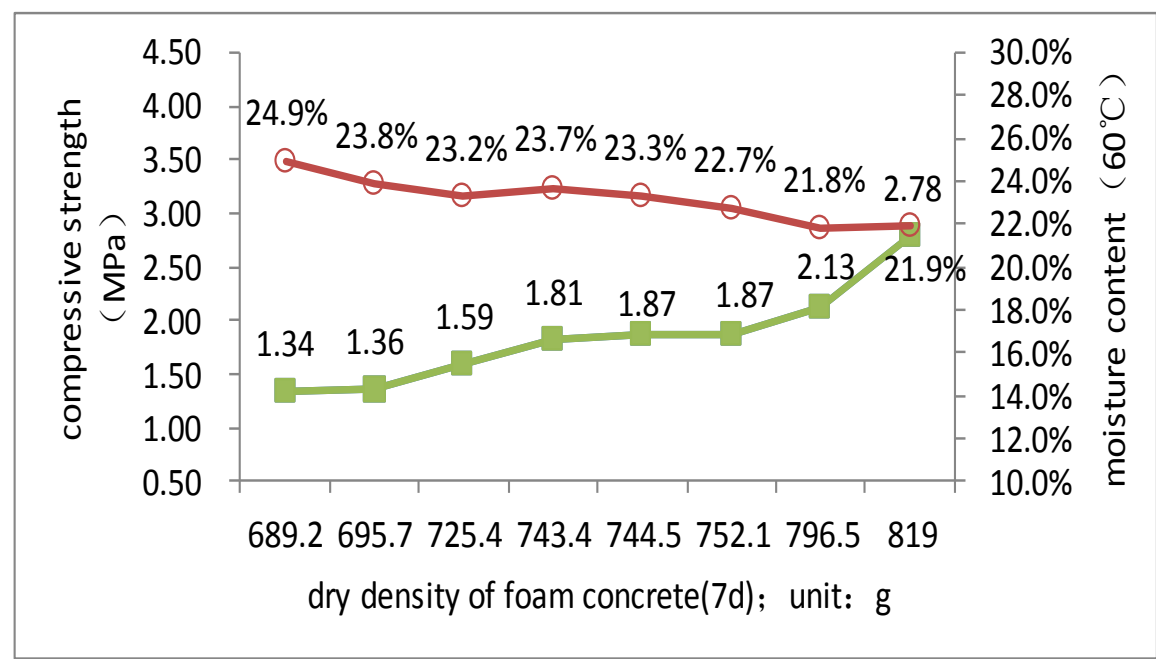

Fig.3 Effects of dry density of foam concrete on compressive strength and water content (Maintenance period for 7d)

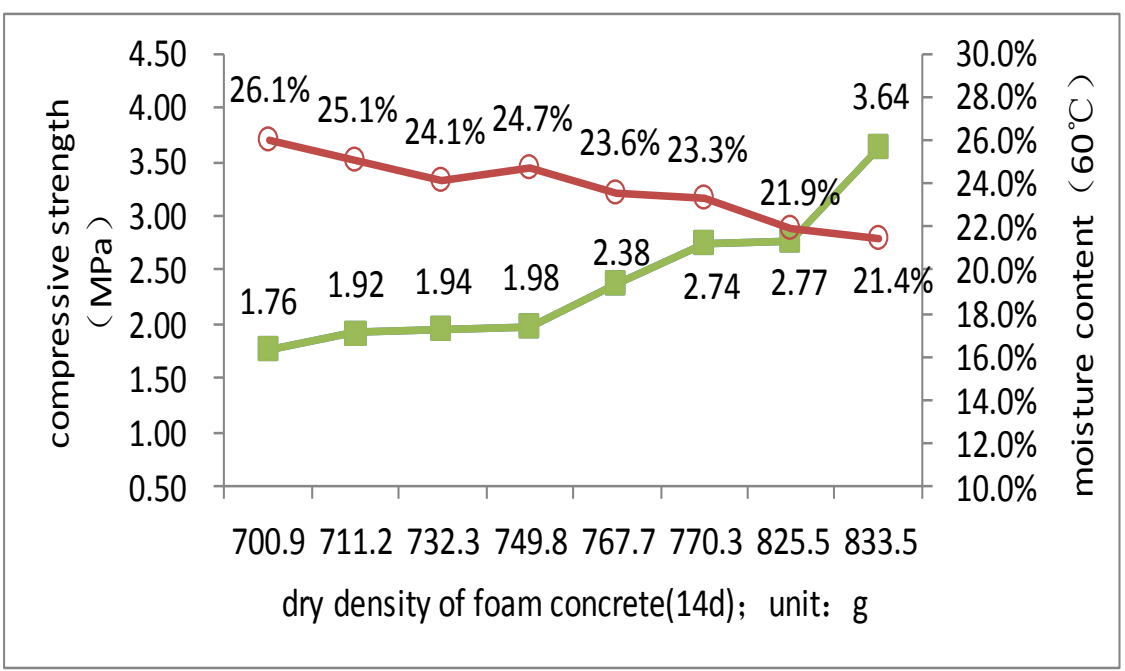

Fig.4 Effects of dry density of foam concrete on compressive strength and water content (Maintenance period for $14 d$ ) 


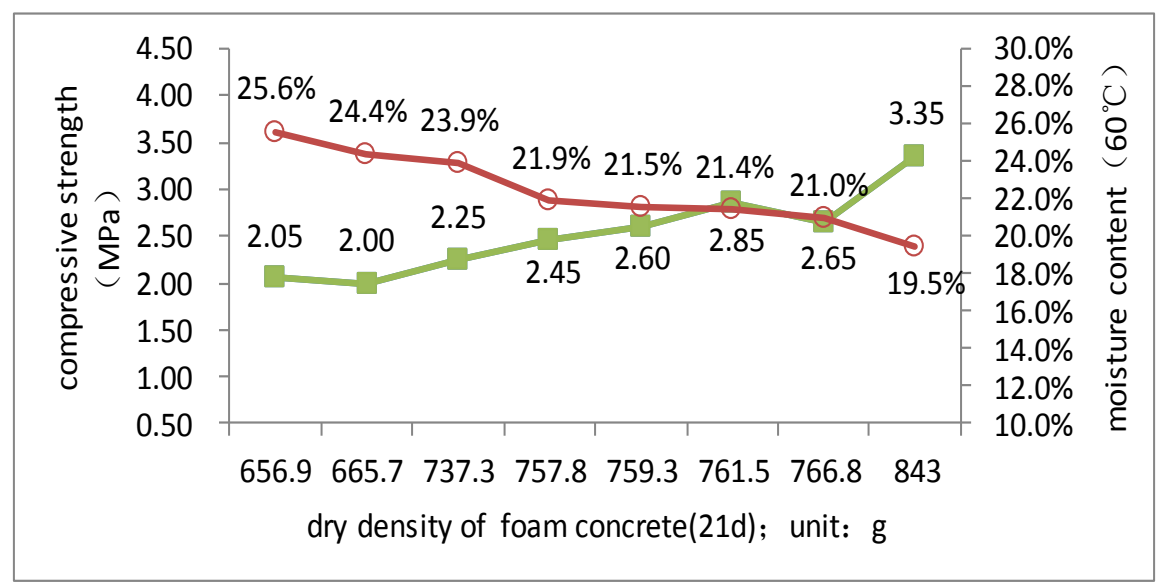

Fig.5 Effects of dry density of foam concrete on compressive strength and water content (Maintenance period for 21d)

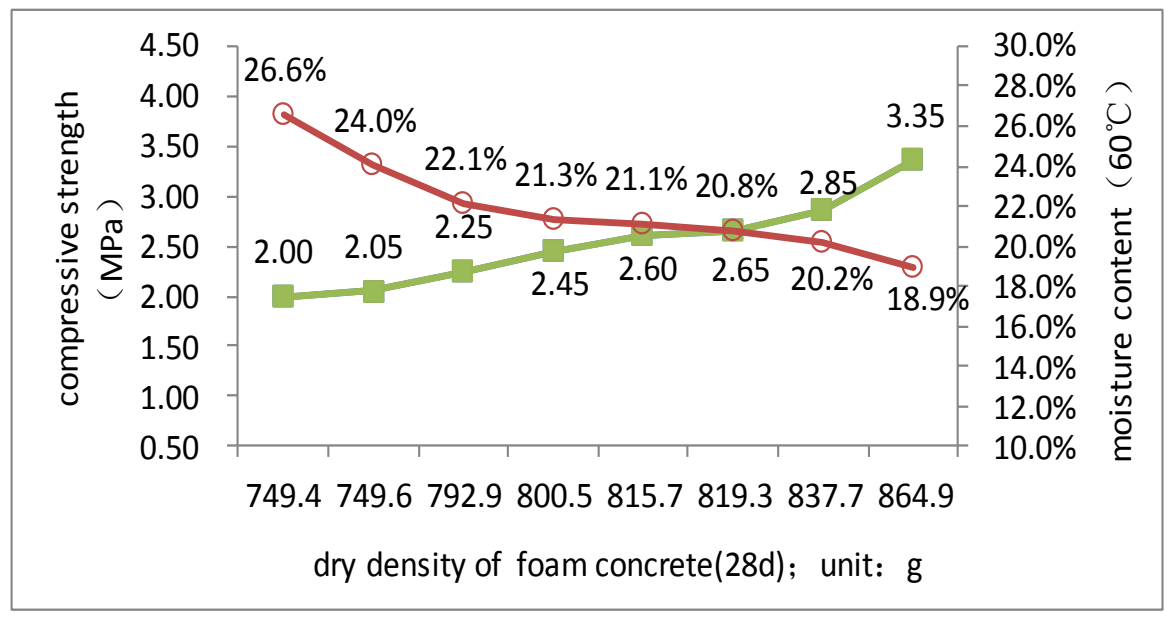

Fig.6 Effects of dry density of foam concrete on compressive strength and water content (Maintenance period for 28d)

As can be seen from Figures 1 to 6:

(1) With increasing dry density, compressive strength increased, while reducing the moisture content. Foam concrete load is borne by the solid phase, small porosity and pore can't bear any load, the pore is the main source cement performance defects. So dry density increased, the solid filling rate increases, the compressive strength of foam concrete is increased, corresponding lower porosity, moisture content is decreased

(2)As the curing period extended, Foam concrete maximum dry density and the minimum dry density corresponding to the compressive strength of difference was grown, Foam concrete maximum dry density and the minimum dry density corresponding moisture content difference was grown. The hydration reaction of cement particles is continued more cement and sand content in unit volume of foam concrete, dry density is bigger, cement reaction is also generate more.

\section{Influence of Standard Curing Period on Compressive Strength of Foamed Concrete}

(1) As can be seen from Figure 7, with the extension of curing time, the compressive strength of foam concrete increases.

(2) (2) \# 7 is the smallest of dry density in the group; the compressive strength is less than the other groups. \# 2 is the largest dry density in the group; compressive strength is significantly higher than the other groups. In the same curing period, difference of the two groups corresponding to the strength is bigger, and along with the prolongation, difference 
showed a trend of increase. So compressive strength of the foam concrete is highly affected by the dry density.

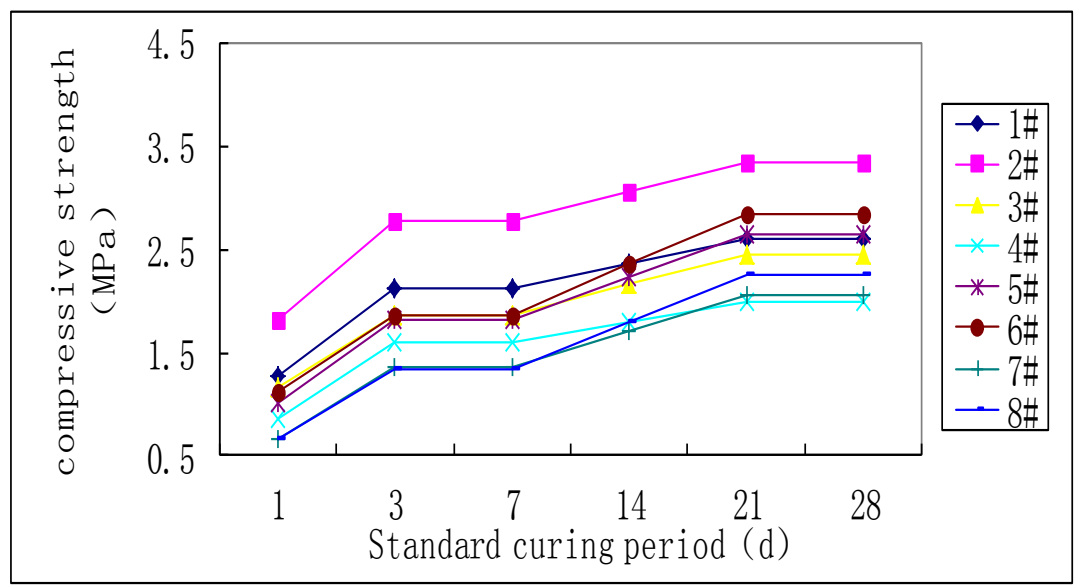

Fig.7 Compressive strength of each group foam concrete in different curing period

\section{The Relationship of Foam Concrete between Compressive Strength and Water Content at the Standard Curing 28 Day}

According to the test groups of the strength of the foam concrete after standard curing $28 \mathrm{~d}$, fitting in $60{ }^{\circ} \mathrm{C}$ drying conditions, the relation between the foam concrete compressive strength and moisture content reached 0.9939 , indicating that the moisture content has a good research value when drying temperature is $60{ }^{\circ} \mathrm{C}$.

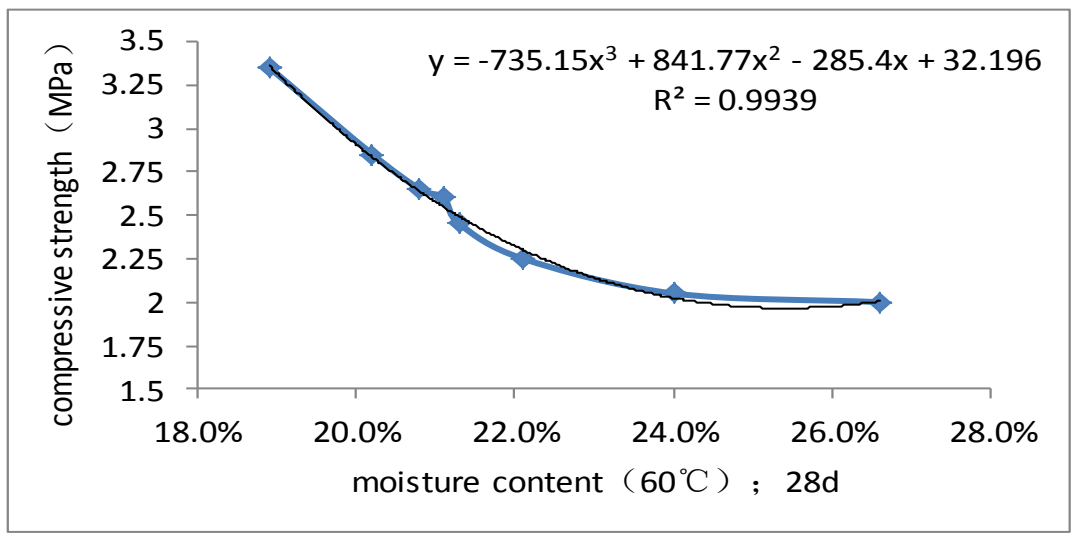

Fig. 8 The relationship between moisture content and compressive strength (standard curing period is $28 \mathrm{~d}$ )

\section{Conclusion}

(1) With the increase of foam concrete dry density, compressive strength increases, the moisture content reduce.

(2) Compressive strength of the foam concrete is highly affected by the dry density.

(3) $60{ }^{\circ} \mathrm{C}$ as foam concrete drying temperature measured the moisture content is valuable to research.

\section{Reference}

[1] Yan Zhenjia, He Yanjun. Practical production of foamed concrete technology [M]. Beijing: Chemical Industry Press, 2006:42-43.

[2] Zhang Leilei, Wang Wuxiang. Research progress and application of foam concrete [J]. Building block and block construction, 2010(1):38-42. 
[3] Wang Cuihua, Pan Zhihua. Synthesis and foam stability of protein foaming agent [J]. Journal of Nanjing University of Technology, 2006, 20(4):92-96.

[4]Yin Bing, Liu Cailin, et al. Animal protein foaming agent for concrete preparation and foaming performance test [J]. New building materials, 2007(7):8-11.

[5] Yu Shuijun, Wang Yulong, Lawrence Chou, et al. Study on the synthesis and properties of composite animal and plant protein foaming agent system [J]. Journal of Henan Polytechnic University (NATURAL SCIENCE EDITION), 2011, 30 (3): 331-335.

[6] Ding Qi. Study on a new type of high performance concrete foaming agent [J]. New building materials, 2007(10):16-18. 